\title{
New records and updated distribution of Myopa metallica Camras 1992 (Diptera: Conopidae: Myopinae) in Chile by using integrative collection methods
}

\section{Nuevos registros y distribución actualizada de Myopa metallica Camras 1992 (Diptera: Conopidae: Myopinae) en Chile usando métodos de colecta integrativa}

\author{
Rodrigo M. Barahona-Segovia ${ }^{1,2,3^{*}}$, Laura Pañinao-Monsálvez 2,4 \& Matías Barceló2,5 \\ ${ }^{1}$ Laboratorio de Ecología de Ambientes Fragmentados (LEAF), Departamento de Ciencias Biológicas Animales, Facultad de \\ Ciencias Veterinarias y Pecuarias, Universidad de Chile, Santiago, Chile. \\ ${ }^{2}$ Citizen Science program "Moscas Florícolas de Chile", Chile. \\ ${ }^{3}$ Centro de Estudios en Ecología Espacial y Medio Ambiente - Ecogeografía, Santiago, Chile. \\ ${ }^{4}$ Facultad de Ciencias Forestales, Universidad de Concepción, Concepción, Chile. \\ ${ }^{5}$ Laboratorio de Conservación Biológica, Departamento de Ciencias Ecológicas, Facultad de Ciencias, Universidad de Chile, \\ Santiago, Chile. \\ *E-mail: rbarahona13@gmail.com
}

\begin{abstract}
Myopa metallica Camras1992 is a parasitic fly, endemic to Chile, whose distribution was unknown. In this study, four new localities are reported between the Atacama and Metropolitan regions using citizen science. Our work breaks down the methodological barriers, providing a distribution for a rare and conspicuous thick-headed fly.
\end{abstract}

\begin{abstract}
RESÚMEN
Myopa metallica Camras, 1992 es una mosca parásita, endémica de Chile, cuya distribución era desconocida. En este estudio se reportan cuatro nuevas localidades entre la región de Atacama y Metropolitana usando ciencia ciudadana. Nuestro trabajo rompe las barreras metodológicas, proporcionando una distriución para una especie de mosca conspicua y rara.
\end{abstract}

Thick-headed flies (Diptera: Conopidae) are represented by 863 species distributed worldwide except for both Antarctica and Pacific Islands (see Freeman 1996, Marshall 2012, Gibson \& Skevington 2013, Stuke 2017). These species are considered endoparasitoids, principally bees and aculeate wasps, although also cockroaches and crickets for the genus Stylogaster Macquart (see Lopes, 1937, Woodley \& Judd, 1998 and Skevington et al. 2010); using flowers as watch sites for oviposition, showing an in-flight attack system (Freeman 1996, Marshall 2012, Stuke 2017). In addition, adults are nectarivorous, pollinators and show a hilltop mating behavior (Kendall \& Solomon 1973, Skevington et al. 2010, Marshall 2012). However, in many parts of the world, this group of flies is barely known, particularly in the Neotropics, a region where the knowledge about natural history and ecology in all species of thick-headed flies is deficient.

Neotropical thick-headed flies are represented by more than 220 species in 14 genera such as Zodion, Physocephala,
Physoconops or Stylogaster (Skevington et al. 2010, Stuke 2017). The principal investigation on Neotropical Conopidae has been in taxonomy (Camras 1955, 1957, 1992, 1996, Pearson \& Camras 1978), host-parasite relationships (Melo et al. 2008, Stuke et al. 2011, Stuke and Cardoso 2013) or checklist (Stuke \& Skevington 2007, Rocha \& Mello-Patiu 2016). In this sense, native and endemic thickheaded flies in Chile are poorly known, represented by nine species, including the genus Mallochoconops Malloch 1933, Physocephala Schiner 1861, Zodion Latreille 1796 and Myopa Fabricius 1775. This last genus has one single species that can be found in South America, only in Chile, where it is endemic: Myopa metallica Camras 1992. Recently, this species was rediscovered in Northern Chile, by using the citizen science method, after 46 years of absence of occurrences (Barahona-Segovia et al. 2017). This new record that was located to $1,352 \mathrm{~km}$ from the type locality, opens the question if the new record could really be a cryptic new species related to M. metallica or if the 
absence of distributional information is due to the lack of systematic collections between both records (BarahonaSegovia et al. 2017). This conspicuous fly is recognized by its shiny red head, antennal segments, eyes, and halters, as well as its evident metallic blue color in the thorax and in a part of the abdominal segments (Barahona-Segovia et al. 2017; Fig. 1).

In this natural history note, we remark the necessity of generating new collections due to a large amount of territory without occurrences and the presence of different ecosystems in these geographical gaps, which could be complemented by other methods such as reviewing entomological collections or using citizen science program. According to this communication, we reported new records and updated distribution of the poorly known species $M$. metallica based on i) the active collection between The Atacama Province and Sclerophyllous matorral in central Chile (Morrone 2014), ii) the review of entomological collections and iii) the use of the citizen science program Moscas Floricolas de Chile (www.facebook.com/groups/774986852548819/) as external dataset.

Between September and November 2017, Chile presented the phenomenon of flowering desert, which manifest after winter rains and follow by a marked increase in the number and richness of endemic plants (i.e. 19 mm; Vidiella et al. 1999). In this time period, spring temperatures increase over $22-24^{\circ} \mathrm{C}$ and entomological fauna is active between Atacama and Maule province for mating. Therefore, we carried out three systematic collections using the biogeographical realms (BR) proposed by Morrone $(2006,2014)$. In each BR, we realized transects of 100 meters each and they were separated by a minimum of 500 meters. The BR surveyed were: i) Atacama province (i.e. from Caldera to Vallenar in the flowering desert bloom $(n=19))$, ii), Coquimbo province (i.e. from Huentelauquen to La Ligua $(\mathrm{n}=12))$ and iii) Santiago province in Andean region (i.e. from El Arrayán to El Manzano in Santiago Metropolitan Region $(n=7))$. Insects were captured by active collection and entomological net by using 10 handnet points moving in zigzag. All BR present different priority sites for conservation (Muñoz et al. 1997) as well as different ecosystems. On the other hand, during January 2016 to December 2017, we carried out a comprehensive revision of native flies in entomological collections (i.e. MNHNC, IEUMCE, MEUC, MZUC, UACH and SAG; see in acknowledgments). In addition, the citizen science program that started in 2015 has +3100 volunteers, including several worldwide recognized dipterologists. Photographic records from this source were identified by authority in the family: both Jens-Hermann Stuke and by the first author.

Our results showed that the combination of all methods generated four new records between Caldera and Santiago Metropolitan Region: i) Carrizal Bajo (by active collection), 18.vii.2017, Leg. R. Barahona-Segovia (Deposited in MEUC); ii) Llanos de Challe National Park (by citizen science), 13.viii.2017, Leg. Gabriela Germain; electronical

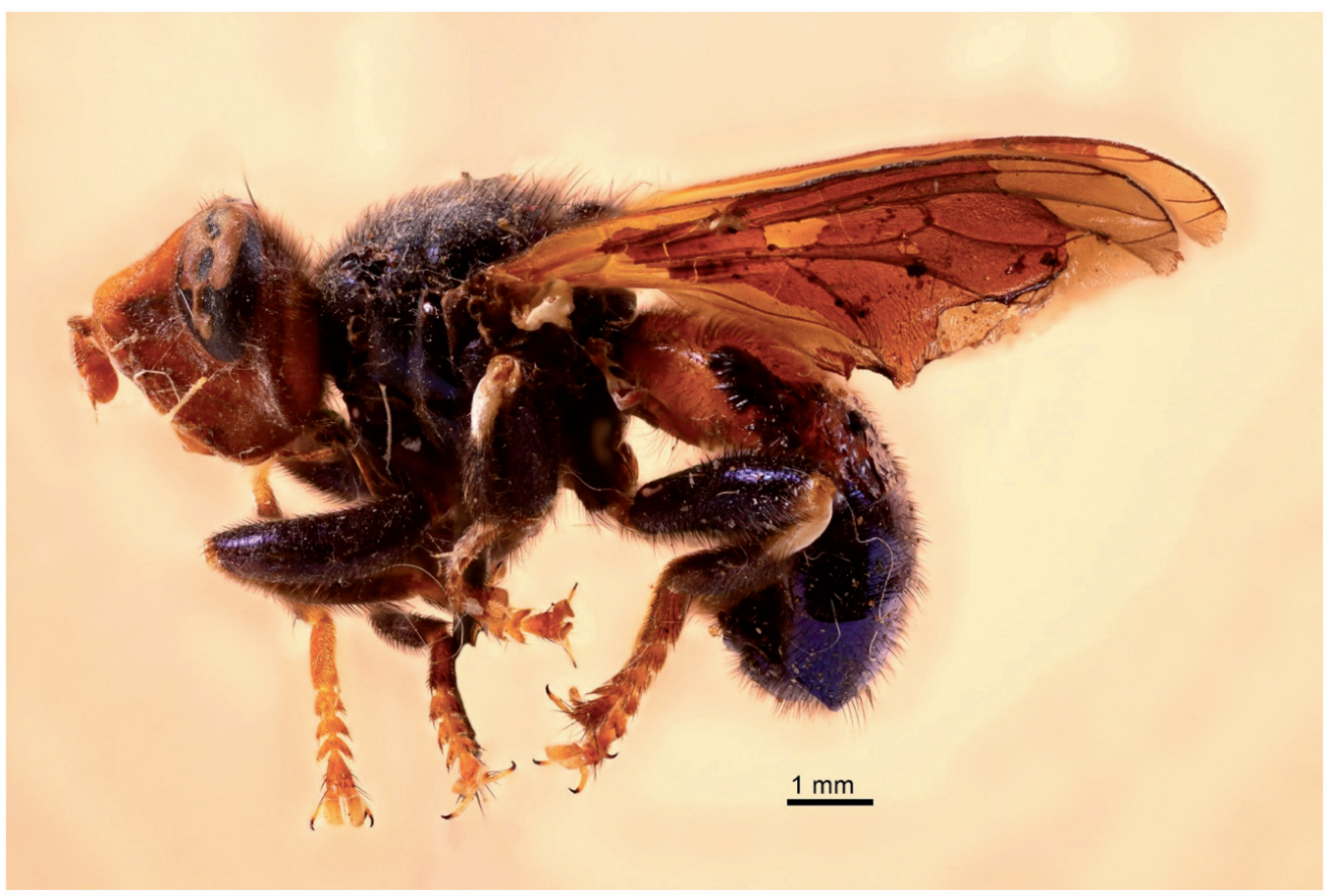

Figure 1. General lateral habitus of Myopa metallica Camras 1992 with characteristic blue-reddish metallic color. Bar represents 1mm scale. / Vista lateral general de Myopa metallica Camras 1992 con su característico color metálico azul-rojizo. Barra representa escala de 1mm. 
voucher in our citizen science program (https://www. facebook.com/photo.php?fbid=10213742742547874\&se $\mathrm{t}=$ pcb.1382875211759977\&type $=3 \&$ theater\&ifg=1); iii) Las Breas, Río Hurtado, Leg. L. E. Peña (by revision of entomological collection and deposited in MEUC) and iv) Farellones, 31.xii.1997, Leg. Francisco Ramírez (by active collection, deposited in the private collection of the collector and then showed in citizen science; https://www.facebook. com/photo.php?fbid=10209698349567864\&set=gm. 14581 99044227593\&type $=3 \&$ theater\&ifg=1) (Figs. 2a, 2b).

Our results suggest that integrative methods could be an alternative method to know about the distribution of rare species. The use of the citizen science method to gather occurrence data and modelling the potential distribution even for potential insect invasion - is recognized worldwide by many conspicuous insect species such as bumblebees (Montalva et al. 2017, Suzuki-Ohno et al. 2017) or ladybugs (Grez et al. 2016). However, in conspicuous flies, it could be a unique opportunity to offset the high Wallacean shortfall in this insect group (Barahona-Segovia et al. 2017). One example of this positive interaction is the use of social media and open access cooperative information of taxonomist, which can help to increase the known distribution of water beetles (Suprayitno et al. 2017). With further information about this species expanded by social media, is highly probable that new records can appear and thus, new collection and data about their habitat and ecology can be carried out.

Future work must be directed to know the potential host and habitat preferences of this fly. Barahona-Segovia et al. (2017) suggest that this species could attack Megachile bee species in Northern Chile due to the fact it is the most abundant species in the area. On the other hand, the potential bee host could be high due to the high diversity of bees in Chile (Montalva \& Ruz 2010). Habitat preferences or phenology could also be proportionated by a citizen volunteer by using social media (see an example in Suprayitno et al. 2017; Fig. 2c). With this information, it could be possible to combine some biotic or abiotic variables to know the most important environmental conditions or habitat requirements for M. metallica or even modelling the distribution by using scarce occurrence data (Miličić et al. 2017). In conclusion, our work breaks down barriers between classic methods and existing technology to provide an updated distribution of an endemic, conspicuous and rare thick-headed fly.

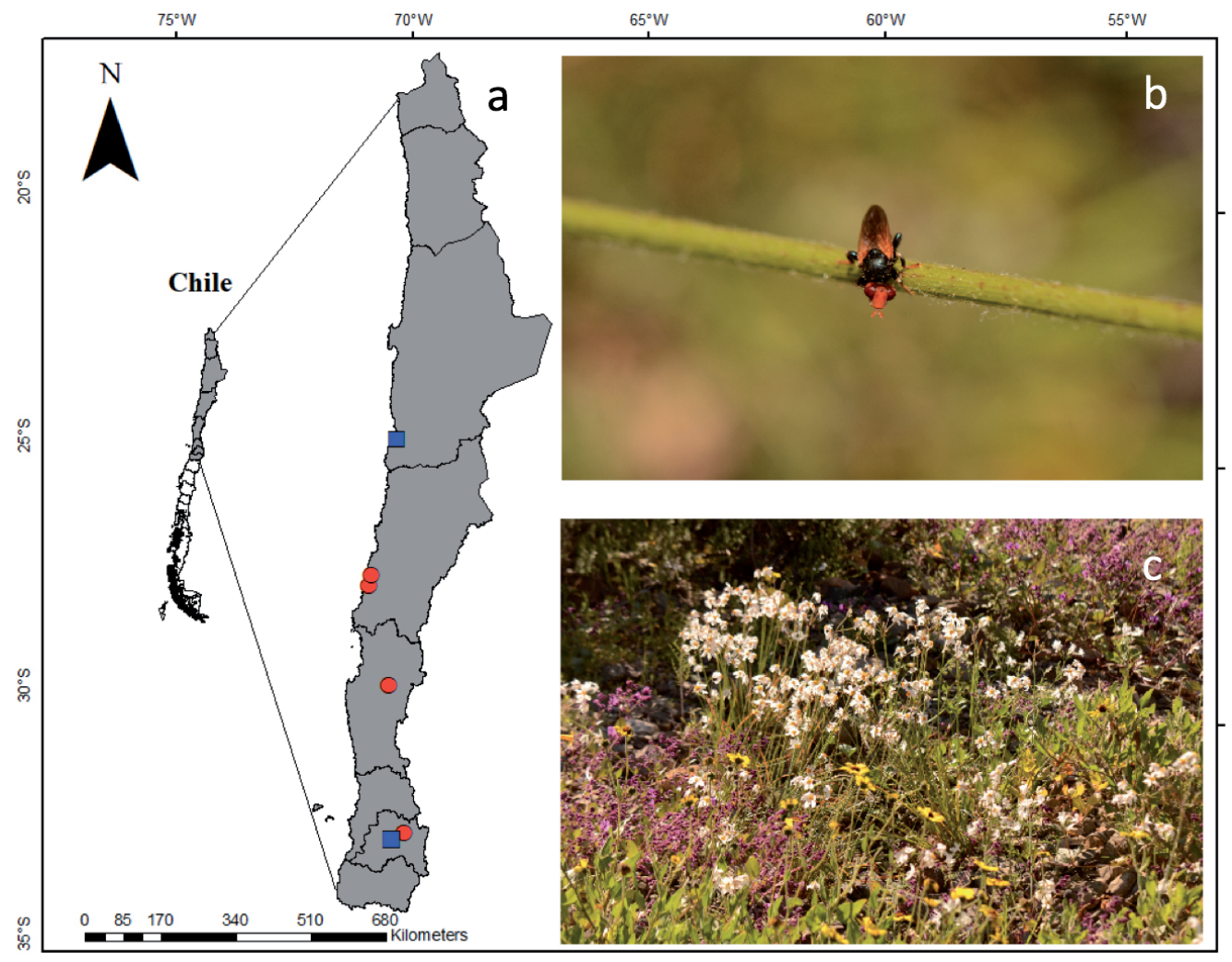

FIgURE 2. Distributional map of Myopa metallica Camras 1992: a) new records; blue squares represent data shown in Barahona-Segovia et al. (2017) and red circles, new records by different methods of collect; b) in situ M. metallica (photo courtesy of Gabriela Germain Fonck) and c) flowering desert in the habitat of M. metallica and occupied as attack sites. / Mapa de distribución de Myopa metallica Camras 1992: a) nuevos registros; cuadrados azules representan datos mostrados por Barahona-Segovia et al. (2017) y círculos rojos, nuevos registros por diferentes métodos de colecta; b) M. metallica en vivo (fotografía cortesía de Gabriela Germain Fonck) y c) desierto florido en el hábitat de M. metallica y ocupados como sitios de ataque. 


\section{ACKNOWLEDGMENTS}

We thanks to Mario Elgueta from Museo Nacional de Historia Natural (MNHNS), Sergio Rothman from Servicio Agrícola y Ganadero (SAG), Miriam Fernández and Jorge Artigas from Museo de Zoología of Universidad de Concepción (MZUC), Patricia Estrada from Instituto de Entomología of Universidad Metropolitana de Ciencias de la Educación (IEUMCE), Cecilia Ruiz from Colección Ernesto Krahmer of Universidad Austral de Chile (UACH) and specially, the valuable help of Danilo Cepeda, from Museo L. E. Peña of Universidad de Chile (MEUC). Also, we appreciate the help of Daniela Salinas in field work, Jun Hee Kang by correction in English, Gabriela Germain Fonck and Andrés Ramírez by citizen reports and pictures of M. metallica and Jens-Hermann Stuke for early taxonomic identification and L.S.G. Rocha for their comments and review.

\section{REFERENCES}

Barahona-Segovia, R.M., Castillo Tapia, R., Pañinao Monsálvez, L. 2017. First record of Myopa metallica Camras, 1992 (Diptera: Conopidae: Myopinae) in Northern Chile after 46 years: A case study of the success of citizen science programs. Journal of Insect Biodiversity 5: 1-8.

CAmras, S. 1955. A review of the new world flies of the genus Conops and allies (Diptera: Conopidae). Proceeding of the United State Museum 105: 155-187.

CAmras, S. 1957. A review of the new world Physocephala (Diptera: Conopidae). Annals of the Entomological Society of America 50: 213-218.

Camras, S. 1992. New Neotropical Conopidae (Diptera). Entomological News 103: 83-85.

CAmras, S. 1996. New information on the new world Physocephala (Diptera: Conopidae). Entomological News 107: 104-112.

Gibson, J.F., Skevington, J.H. 2013. Phylogeny and taxonomic revision of all genera of Conopidae (Diptera) based on morphological data. Zoological Journal of the Linnean Society of London 167: 43-81.

Grez, A.A., Zaviezo, T., Roy, H.E., Brown, P.M.J., Bizama, G. 2016. Rapid spread of Harmonia axyridis in Chile and its effects on local coccinellid biodiversity. Diversity and Distribution 22: 982-994.

Freeman, B.A. 1966. Notes on conopid flies, including insect host, plant and phoretic relationships (Diptera: Conopidae). Journal of Kansas Entomology Society 39: 123-131.

Kendall, D.A., Solomon, M.E. 1973. Quantities of pollen on the bodies of insects visiting apple blossom. Journal of Applied Ecology 10: 627-634.

LoPES, H. DE SOUZA. 1937. Contribução ao conhecimento do genero Stylogaster Macquart. 1835, (Dipt. Conopidae). Archivos de Instituto de Biologia Vegetal 3: 257-293.

Marshall, S.A. 2012. Flies: the natural history and diversity of Diptera. Firefly Book Ltda., New York, 616 pp.

Melo, G.A.R., Faria JR., L.R.R., Marchi, P., DE CARVAlho, C.J.B. 2008. Small orchid bees are no safe: parasitism of two species of Euglossa (Hymenoptera: Apidae: Euglossina) by conopid flies (Diptera: Conopidae). Revista Brasileira de Zoologia 25: 573-575.
Miličić, M., Vujić, A., Jurca, T., Cardoso, P. 2017. Designating conservation priorities for Southeast European hoverflies (Diptera: Syrphidae) based on species distribution models and species vulnerability. Insect Conservation and Diversity 10: 354-366.

Montalva, J., Ruz, L. 2010. Actualización de la lista sistemática de las abejas chilenas (Hymenoptera: Apoidea). Revista Chilena de Entomología 35: 15-52.

Montalva, J., Sepulveda, V., Vivallo, F., Silva, D.P. 2017. New records of an invasive bumble bee in northern Chile: Expansion of its range or new introduction events? Journal of Insect Conservation 21: 657. DOI:10.1007/s10841-0170008-x.

Morrone, J.J. 2006. Biogeographic areas and transition zones of latin america and the caribbean islands based on panbiogeographic and cladistic analyses of the entomofauna. Annual Review of Entomology 51: 467-494.

Morrone, J.J. 2014. Biogeographical regionalisation of the Neotropical region. Zootaxa 3782: 1-110.

Muñoz, M., NúÑEZ, H., YÁÑEZ, J. 1997. Libro rojo de los sitios prioritarios para la conservación de la biodiversidad en Chile. Ambiente y Desarrollo 13: 90-99.

Pearson, D.L., Camras, S. 1978. Notes and key to Neotropical Zodion (Diptera: Conopidae). Journal of the Kansas Entomological Society 51: 198-206.

Rocha, L.S.G., Mello-Patiu, C.A. 2016. Family Conopidae. Zootaxa 4122: 561-565.

Skevington, J., Thompson, F.C., Camras, S. 2010. Conopidae (Thick-headed flies). In: Brown, E.V., Borkent, A., Cumming, J.M., Wood, D.M., Woodley, N.E., Zumbado, N.A. (Eds) Manual of Central American Diptera, vol. 2: 847-856. NRC Research Press, Ottawa.

Stuke, J.-H., Skevington, J. 2007. The Conopidae of Costa Rica (Diptera) (Part 1: Conopinae-Conopini \& Tropidomyiini). Zootaxa 1528: 1-40.

Stuke, J.-H., Lucia, M., Abrahamovic, A.H. 2011. Host records of Physocephala wulpi Camras, with a description of the puparium (Diptera: Conopidae). Zootaxa 3038: 61-67.

Stuke, J.H., Cardoso, C.F. 2013. Physocephala inhabilis (Walker) (Diptera: Conopidae) parasitizing Megachile (Moureapis) maculata Smith (Hymenoptera: Megachilidae). Studia dipterologica 20: 39-43.

Stuke, J.-H. 2017. Conopidae (Diptera) (World Catalogue of Insects 15). Brill, Leiden, Sweden. 354 pp.

Suprayitno, N., Narakusumo, R., von Rintelen, T., Hendrich, L., BALKe, M. 2017. Taxonomy and Biogeography without frontiers - WhatsApp, Facebook and smartphone digital photography let citizen scientists in more remote localities step out of the dark. Biodiversity Data Journal 5: e19938. DOI:10.3897/BDJ.5.e19938

Suzuki-Ohno, Y., Yokohama, J., Nakashizuka, T., Kawata, M. 2017. Utilization of photographs taken by citizens for estimating bumblebee distributions. Scientific Report 7: 11215, DOI:10.1038/s41598-017-10581-x.

Vidiella, P.E., Armesto, J.J., Gutiérrez, J.R. 1999. Vegetation changes and sequential flowering after rain in the southern Atacama Desert. Journal of Arid Environments 43: 449-458.

Woodley, N.E., JudD, D.D. 1998. Notes on the host, egg, and puparium of Stylogaster biannulata (Say) (Diptera: Conopidae). Proceedings of the Entomological Society of Washington 100: 658-664. 